\title{
La imagen sigilar: el sello del Estudio de Salamanca
}

\author{
Lucía Lahoz \\ Universidad de Salamanca \\ lahoz@usal.es
}

RESUMEN: Análisis del sello de la Universidad de Salamanca, concedido por Alejandro IV como primera imagen institucional, identitaria y autentificadora. La técnica, tipología e iconografía figurativa de la imagen se implican en su funcionamiento social e ideológico. El sello es la matriz y su impronta en todo tipo de soportes, desde documentos que ratifican el sistema de la universidad y difunden su imagen en lugares lejanos, hasta las fachadas monumentales que la proyectan en la propia urbe. En la Fachada Rica salmantina, la imagen proclama y actualiza la titularidad papal representando una escena diplomática ad vivum, empleando una retórica visual plena de intención cuando la universidad pugna por su estatus y autonomía frente a las instituciones catedralicias y monárquicas.

PALABRAS CLAVE: Sigilografía; Sello; Salamanca; Imagen Universitaria; Papa Alejandro IV; Iconografía.

\section{The Sigil Image: The Seal of the University of Salamanca}

ABSTRACT: Analysis of the seal of the University of Salamanca, granted by Pope Alexander IV as the first institutional, identifying and authenticating image. The technique, typology, figurative iconography of this image are all involved in its social and ideological functions. The seal is the matrix and its imprint is on all kinds of media, from documents that ratify the university system and spread its image in distant places to the monumental façades that project it in the city. In the Fachada Rica of Salamanca, the image proclaims and updates papal ownership by depicting an ad vivum diplomatic scene, employing a visual rhetoric full of intention when the university was struggling for its status and autonomy against the cathedral and monarchical institutions.

KEYWORDS: Sigillography; Seal; Salamanca; University Image; Pope Alejandro IV; Iconography.

Recibido: 21 de febrero de 2021 / Aceptado: 9 de junio de 2021.

\section{Introducción}

En las Partidas de Alfonso X se ratifica: «la imagen del rey, como su sello en que está su figura son su remembranza do el no está». El texto legislativo formula la naturaleza de la impronta sigilar, pero la información también compete a la teoría de la imagen, a su función y significado. El objetivo del ensayo versará sobre la naturaleza e iconografía de los sellos de la Universidad de Salamanca, institución precisamente muy favorecida por el rey Sabio', así como los cambios operados en la producción monumental del registro sigilar.

En el estudio del sello el discurso historiográfico ha privilegiado el aspecto arqueológico, utilizado como una fuente de imágenes vanamente documental. Se ha insistido sobre su papel estrictamente diplomático, con el propósito de validar o autentificar actas, en detrimento de las funciones sociojurídicas o de sus cometidos ideológicos o antropológicos (Pastoreau 1996: 278). En los últimos años se asiste a un auténtico giro, como la copiosa bibliografía ratifica (Riesco, 1978; Menéndez Pidal de Navascués, 1990; Fernández-Xesta y Vázquez, 2016; Menéndez Pidal de Navascués, 2018).

Entre las estrategias discursivas publicitarias de la Edad Media, el sello proclama, propaga, difunde y celebra la imagen de su propietario, se convierte en un emblema parlante, en un signo elocuente que conmemora a su poseedor, con indepen-

Cómo citar este artículo: LAHOZ, Lucía, «La imagen sigilar: el sello del Estudio de Salamanca», Boletín de Arte-UMA, n. ${ }^{\circ} 42$, Departamento de Historia del Arte, Universidad de Málaga, 2021, pp. 109-118, ISSN: 0211-8483, e-ISSN: 2695-415X, DOI: http://dx.doi.org/10.24310/BoLArte.2021.vi42.12011 
dencia de su condición institucional o privada. El sello es una imagen que circula y que circula a la vez lejos de su lugar de emisión (Pastoreau: 1996: 281). En la práctica investigadora, los diversos registros del género sigilográfico adolecen de un buen trato por la iconografía. «Se trata de un documento figurado que puede mejor que ningún otro procurar un conocimiento realmente profundo de las imágenes medievales» (Pastoreau, 1996: 276).

La iconografía grabada en los sellos de la Edad Media, dada su evidente manifestación de autoridad, tuvo la función de propagar y fortalecer la imagen del titular, convirtiéndose en instrumentos de propaganda prioritarios. El sello entra por méritos propios en la simbología de poder. La impronta timbrada articula una función de validación y pronto adquiere categoría de elemento de autoridad y actúa como signo de poder. En su vigencia redunda su dilatada difusión, se convierten en auténticos mass-media más accesibles a un mayor número de personas, de hecho, al ampliar su audiencia se redobla su eficacia. El recurso del sello como instrumento exclusivamente de validación ofrece varias vertientes, se sabe de su empleo y empeño con valor de jurisdicción, pero igualmente denota propiedad, símbolo de autoridad, y hasta adscripción (Pastoreau, 1986: 516). A lo que se añade su carácter eminentemente visual en una sociedad donde la experiencia sensitiva ocular alcanza cotas inéditas que articulan hasta sistemas de pensamiento. La importancia adquirida por la experiencia de la visión no solo trasformó la vida religiosa sino que impuso un sofisticado sistema visual de la que participó la heráldica en estos momentos, como bien apuntaba Camilla, (2005: 20), experiencia que ha de hacerse extensiva asimismo a los sellos, dado que comparten funciones y presupuestos ideológicos. Se trata asimismo de emblematizarse a través de la imagen sigilar.

Por su naturaleza, el sello es a la vez un objeto y una imagen. Como toda imagen salida de un molde, de una matriz, de un punzón o más tarde de una estampa, constituyen ejemplos de imágenes fabricadas en grandes series, mantiene lazos estrechos entre lo uno y lo múltiple. Incluso la misma denominación denota la unión entre el objeto productor y la imagen producida; es frecuente que el mismo vocablo sigillum designe el objeto matriz y la imagen creada a través de la huella impresa (Pastoreau, 1996: 278).

No se ha reparado en la magnitud del alcance de los sellos para el análisis de la imagen, entendida ésta en el sen- tido amplio del término como portadora de significación y con la exigencia de «resituar las imágenes en el conjunto del imaginario social, en la puesta en juego del poder y la memoria» (Schmitt, 1999: 20). Se ha insistido en la tendencia estereotípica de la iconografía sigilar. Pero su análisis ha de atender a un problema esencial: el poder de la imagen, reconocer las funciones iconográficas dentro del sello. Se entenderá como soporte de una estrategia mental. «Como testimonio de un sistema de pensamiento autorizado por un poder cada sello es una parábola de la realidad fundada por ese poder» (Fabre, 2001: 16).

En el tratamiento y la investigación sobre los modelos sigilares acontece una situación equiparable a lo constatado en las mal llamadas artes menores, relegadas a un papel secundario. No se les ha concedido la dimensión exacta adquirida por estos objetos. Se piensa en piezas de categoría inferior, cuando la documentación ratifica la participación de artistas de primera fila, como se constata en el sello de la cofradía de Santiago de París, una obra documentada de Jean Pucelle entre 1319-1324, que registra la implicación de grandes artífices en su ejecución y que contribuye además a la difusión de un estilo o de unas notas formalistas que completan el campo de los intercambios en el sentido más amplio del término. Incluso en su caso se ha defendido la transferencia de influencias del ámbito de las miniaturas (Le Pogam, 19941996: 46-48). El ejemplar parisino a su vez delata el uso del sello por otro tipo de instituciones. De todos modos, la extensa producción sigilar a lo largo de la Edad Media, implicando a todos los estamentos, religioso, laico, civil, eclesiástico, monárquico, institucional, individual, colectivo genera un copioso catálogo que impide analizarlos de modo individual. Por ello el estudio se centrará en el conjunto universitario salmantino.

\section{La imagen sigilar del Estudio de Salamanca}

La concesión del sello

Alejandro IV el 15 de Julio de 1255 a través de la Bula Petitionibus vestris, accediendo a lo solicitado por la universidad, le autoriza para tener sello propio y hacer uso del mismo:

Alexander episcopus servus servorum Dei dilectis filiis universitati magistrorum, rectorum et scholarium Salamantin. salutem 
et apostolicam benedictionem. Petitionibus vestris benignum impertientes assensum, ut commune sigillum habere ac eo uti libere valeatis, devotioni vestrae liberam concedimus auctoritate praesentium facultatem. Nulli ergo omnium hominum liceat hanc paginam nostrae concessionis infrigere vel ei ausu temerario contraire. Si quis autem hoc attemptare praesumpserit, indignationem omnipotentis. Dei te beatorum Petri et Pauli apostolorum ejus se noverit incursurum (Beltrán de Heredia, 1966: 320, doc. $n^{\circ} 11$ )

La medida de la concesión del sello y el uso del mismo concierta el punto de partida, el paso inaugural en la creación de la imagen del Estudio de la Universidad de Salamanca. Se trata, en definitiva, de la primera imagen institucional de la que se tiene constancia, en efecto resulta el primer dato plenamente constatado del recurso a una imagen, entendida en el sentido amplio del término, que sirva para definir a la institución. La concesión y el uso del sello, «era lo que daba a la corporación personalidad propia» (Beltrán de Heredia, 1966: 28). El sello refuerza su entidad corporativa (Alonso, 2004: 97). «La concesión de un sello a una colectividad o universitas implicaba el reconocimiento de personalidad para actuar jurídicamente como persona "authentica" y por eso desde el siglo XIII siempre que un grupo tendía a afirmarse como tal reivindicaba el uso del propio sello para legitimar los actos correspondientes a su función» (Michaud-Quantin, 1970: 299-303).

Los primeros sellos

No ha llegado el sello primitivo otorgado por Alejandro IV. Debido a su cometido simbólico el registro sigilar tiende a perdurar en sus formas a lo largo del tiempo, dado que la eficacia radica en la identificación y ésta se multiplica cuanto mayor sea la vigencia del modelo. Los ejemplos conservados combinan el recurso figurativo con el epigráfico; lo que los singulariza y los hace privativos son los motivos icónicos y los epígrafes y rótulos elegidos que lo componen. Se acompañan de una impronta mayestática y una leyenda con el titulo. El texto de la inscripción menciona también de manera explícita el origen sigilar de estos objetos (Bedos-Rezak, 2006: 337). Debió estar circundado por la leyenda SIGILUM UNIVERSITATIS STUDII SALAMANTINI. El relato de la inscripción, pese a su parquedad, es de una elocuencia absoluta, identifica el Estudio salmanticense perpetuando la memoria de la institución, pero también su autoridad y en definitiva validándola. El cuerpo epigráfico refuerza su alcance y duplica su eco en atención al ámbito letrado al que pertenece y al que se destina, toda vez que lo perpetúa en el tiempo. Además, la inscripción está en el seno de la imagen, no es un añadido, está ontológicamente ligada al proceso de lo visual y en su caso a la recepción del sello (Debiais, 2013: 169). «La inscripción posee una función real en la manifestación y en la emergencia de toda la substancia semántica de la imagen» (Debiais, 2013:181). No se conserva ninguno anterior al siglo XV y el ensayo se centrará en los sellos monumentales del edificio del Estudio Salmantino, las Escuelas Mayores.

«En principio era el sello de forma circular, con el papa y los clérigos acompañados de las armas reales y las pontificias, pues real y pontificia se creó la Universidad» (Álvarez, 1994: 7). En aras de los motivos icónicos de su figuración utilizados, de su tamaño y hasta de la reiteración la idea conviene matizarse. Se ajusta a un modelo de sellos con personajes que se repite de modo sistemático en los registros sigilares universitarios (Le Pogam, 1994: 44).

De partida destaca la tipología elegida, en cuya significación no se había reparado. En su caso se convierte en una imagen circular y una imagen que circula. Como planteaba Pastoreau, la medalla es una imagen circular, que se daba también en algunos sellos, y ese formato articula un significado distinto. El perímetro por excelencia de la imagen occidental es el rectángulo, y el círculo supone una alteración de los códigos artísticos habituales, si bien no llegan a construir un verdadero sistema iconográfico, pero refuerza y da la impresión de cerramiento (Pastoreau, 1988: 240). El formato apuesta por un sello de tipo rueda. Supone una novedad iconográfica introducida primero en la documentación episcopal en el reinado de Alfonso VII por el arzobispo compostelano Gelmírez, como se ha defendido. Después adoptada por otros prelados gallegos a imitación de la «rota» de los privilegios mayores pontificios desde el papado de León X (Carrasco, 2012: 94). Existe constancia de su uso por parte de la monarquía siendo Sancho III, hijo de Alfonso VII, el primero en utilizarlo (Carrasco, 2012: 93 y 94). Si bien el avance de la investigación y nuevas lecturas has demostrado que la rota de Sancho III es falsa, como se ha demostrado (Ga- 
lende y Ávila, 2018). En cualquier caso interés especial articula el origen de la fórmula. El modelo está inspirado en las Bulas pontificias y al adoptarlo como emblema de la Universidad de Salamanca se está revistiendo del significado de ese poder. En efecto el propio formato dentro de toda esa semiología de poder remite a su vindicación pontificia, que los propios motivos iconográficos refuerzan. Ese matiz y proyección papal se subrayan en el propio sello a través de la incorporación figurativa del pontífice, pero también de sus armas. No describe un retrato personal o individual de un papa determinado, sino que se recurre a uno genérico, por tanto, se trata de un retrato institucional ampliando su vigencia en el tiempo. Que uno de los registros iconográficos más difundidos de la institución, como es el matriz sigilar, se centre en la representación icónica del papado a través de su figura y de sus armas, por tanto, de su imagen y su emblema, no resulta baladí, a pesar de no haberse destacado suficientemente.

Que el tratamiento de la monarquía en este sistema icónico queda en clara desventaja, no necesita más argumentación. En realidad, solo están las armas. La imaginería fijada es elocuente. Se privilegia la figuración del pontífice concediéndole el lugar simbólico por excelencia, su imagen ocupa el espacio central y adquiere asimismo un trato de favor a través de la jerarquía mayestática, en efecto queda por posición y tamaño como el eje y el núcleo de la composición. En su caso, al menos los sellos conservados del siglo XV, los estudiantes, caracterizados como clérigos, dos a cada lado, a pesar de lo encorsetado que puede resultar el formato, aparecen ligeramente girados, me pregunto si el contraste con la disposición frontal y el perfil no son modos de composición, que sirven para trasmitir una dualidad de significados y las diferencias de rango, de posición y de jerarquía. Y así suscribir los efectos connotativos divergentes de ambas posturas como medios expresivos. «El perfil humano es por norma general la forma más avanzada y está en función de una tendencia hacia lo concreto y activo, mientras que la forma frontal es las más pronunciada como vehículo de lo sagrado y trascendente» (Schapiro, 1996: 65).

La resonancia se duplica por el formato elegido, dada la difusión y proyección del género donde se fija. Sellos monumentales, formarían parte de todo ese engranaje de validación, atención y dádivas pontificias que se adivina en varias empresas artísticas, que dejan su impronta en la or- ganización, articulación y situación de la propia institución salmantina en todas sus manifestaciones, docentes, legislativas, económicas (Lahoz, 2014). Se inscribe en un panorama de mayor alcance y sin cuya integración y perspectivas no se entiende. Todo este sistema visual se integra y completa en un engranaje y en unas iniciativas destinadas a emplazar a la universidad entre las más importantes del orbe cristiano. Salamanca sigue la tónica habitual donde las universidades comienzan a gravitar sobre la órbita papal.

Sin embargo, al cotejar el modelo sigilar salmantino con el de otras instituciones universitarias se advierte que el sistema figurativo castellano privilegia la representación pontificia, en claro contraste con lo que se consolida para otras corporaciones, tanto en su iconografía como en su formato. De hecho, variado y variopinto es el catálogo de sellos de los centros de saber europeos. En unos, como en Oxford, se prefiere el canciller, flanqueado por académicos y una serie de escolares dispuestos en los laterales ${ }^{2}$. En otros se opta por el santo titular, Santa Catalina para la Universidad de Siena o San Pedro en la de Heildelberg, no faltan tampoco modelos que integran la imagen del rey fundador, como Carlos IV orante ante San Wenceslao, en el de la Universidad de Praga. Desde luego en ninguno, como en el castellano, se consagra al pontífice, se convierte así en buen modelo de intención, reforzado con el propio formato, subrayando su significado pontificio, dado que la propia rueda lo evoca, si bien el modelo circular no es privativo de Salamanca y se da en otras universidades, como Siena por ejemplo o Caen.

En Salamanca los primeros sellos conservados son los monumentales, cuya misma condición redobla su proyección dado su carácter público. Esos ejemplares acotan la propia naturaleza ontológica del sello, al convertirse en una imagen fija. Toda vez que su función radica en proclamar y celebrar la propiedad de la construcción donde se fija.

\section{El sello del zaguán}

En atención a su emplazamiento original el primero que nos ha llegado es el que figura en un clave del zaguán de Escuelas Mayores, cuya descripción se ha realizado más arriba, que Castro supone que imitará el sello de plata que la universidad encargó en 1508 otorgando una cronología en torno a 1509-1512 (1998: 77) [1] y [2]. 


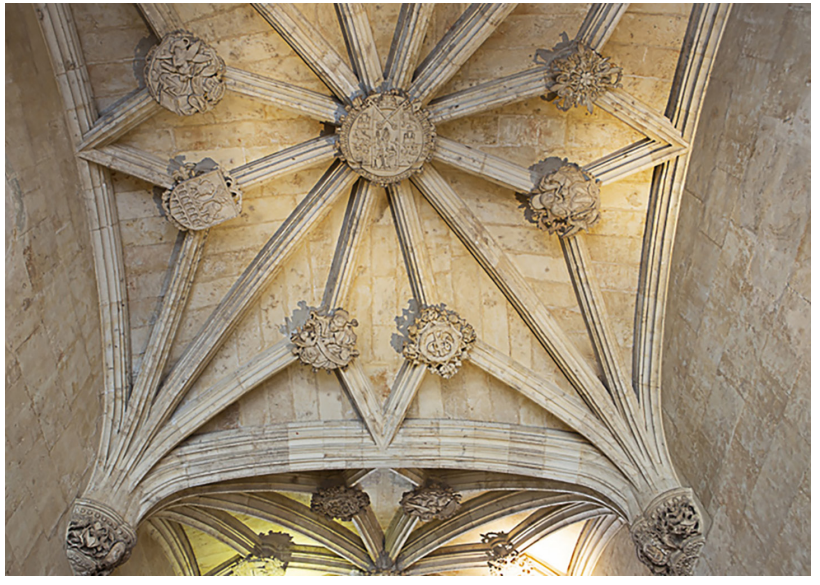

1. Zaguán del edificio de Escuelas Mayores (fotografía: Santiago Santos)

\section{El sello de la escalera}

Una versión distinta ofrece el motivo sigilar monumental que remata la clave de la escalera de Escuelas Mayores, a pesar de que la literatura artística lo ha considerado similar [3]. En efecto, denota diferencias de calado. El tratamiento del pontífice es distinto y cambian la figuración de las armas heráldicas de la monarquía, así como la disposición de los prelados. La auténtica novedad radica en la modificación de la leyenda; se adopta el vocablo signum, abandonando la nominación de sigillum, la solución no debe resultar casual o producto de un lapsus. La literatura sigilar alude a la ambigüedad en el uso de ambos términos en los inicios del desarrollo del género. Sin embargo, en unos momentos, principios del siglo XVI, hacia 1516, cuando la ambigüedad estaba plenamente superada y la lengua latina conformaba el idioma habitual para la audiencia a la que iba destinado, la modificación sospecho la articula toda una intencionalidad. según subraya Debiais: "el texto epigráfico en la imagen aporta un enfoque particular, revela el contenido y el sentido de lo visual» (2013: 181). El término signum reviste mayor fuerza semántica que la acepción sigillum, una denota imagen, mientras que la otra connota sello, y no es lo mismo imagen de la institución que sello del Estudio. «La imagen es frecuentemente definida, en última instancia como representación [...]. Representar es hacer presente lo que no está. La palabra representar es un incentivo. Lo mismo puede ocupar el lugar de una ausencia que ponerla de manifiesto" (Melot,

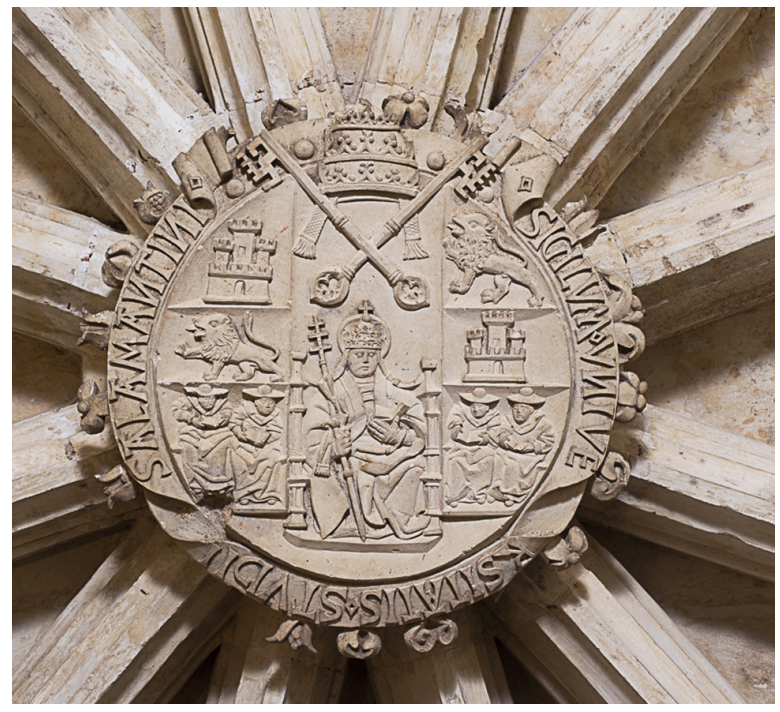

2. Sello del estudio, ubicado en el Zaguán (fotografía: Santiago Santos)

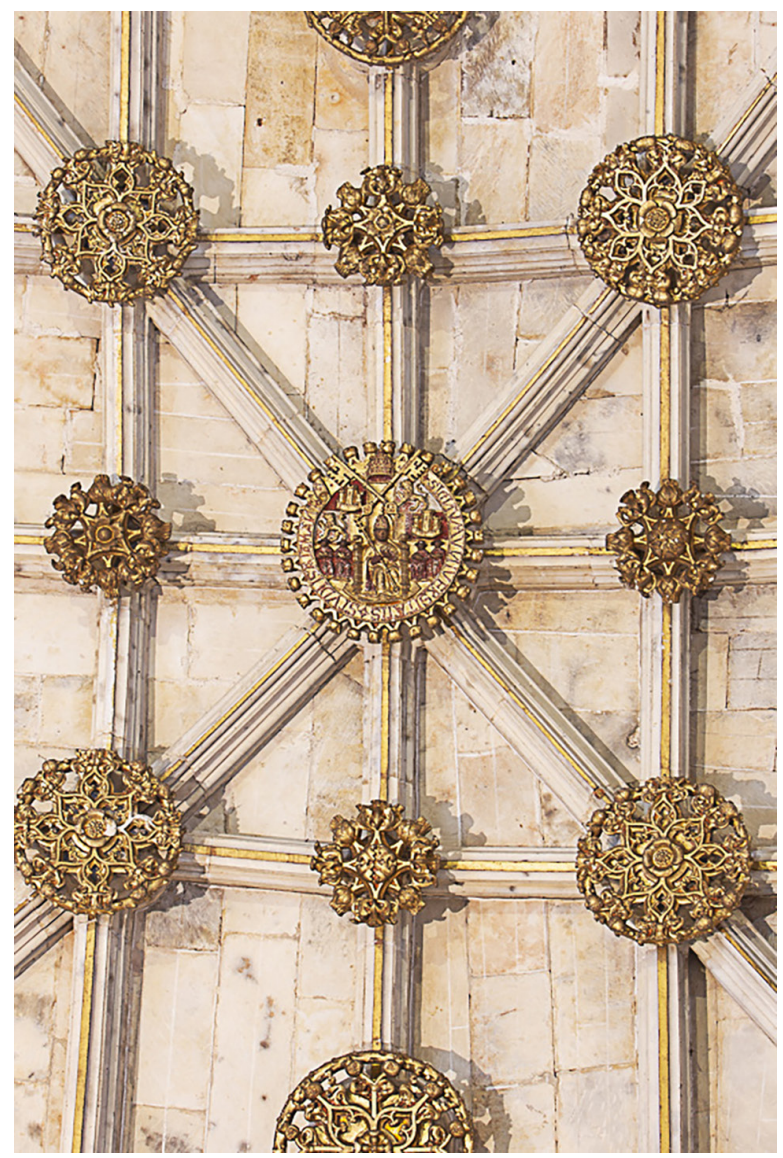

3. Escalera de la Universidad (fotografía: Santiago Santos) 


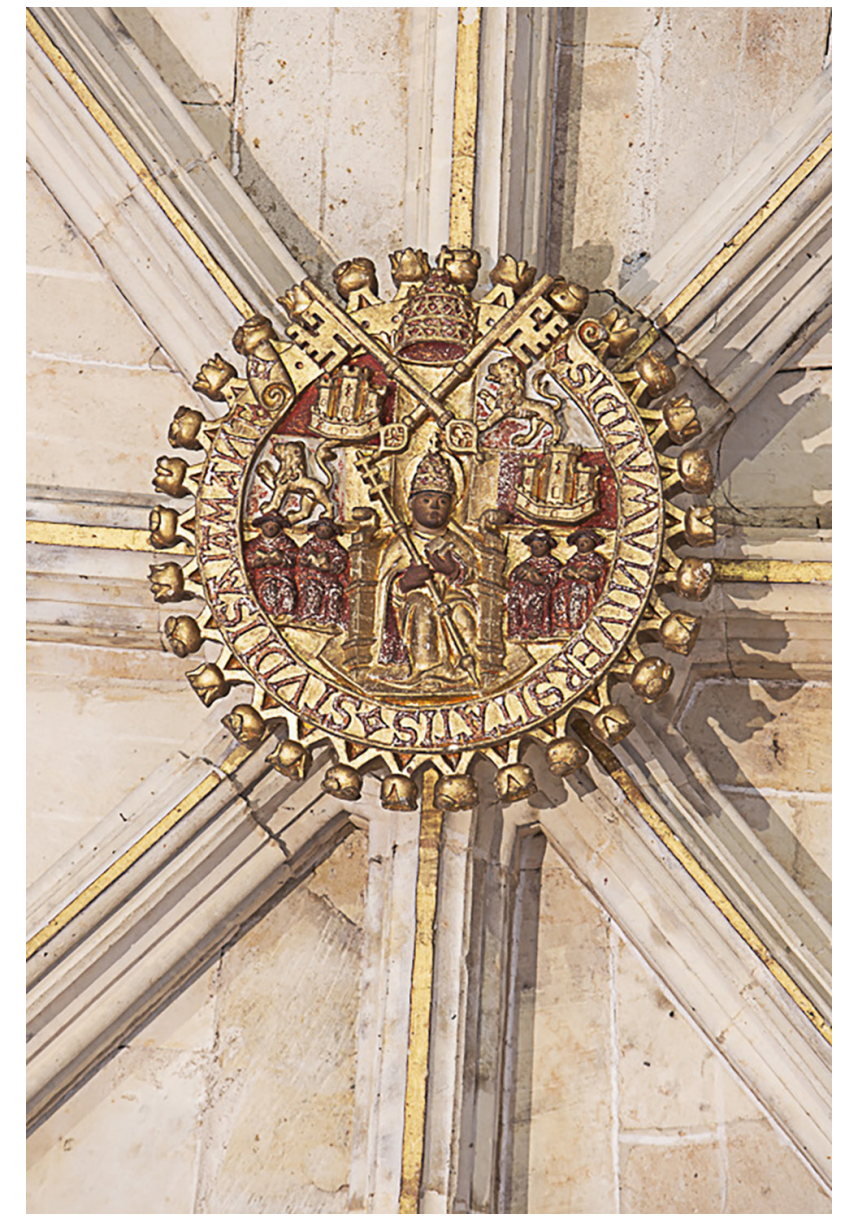

4. Sello de la escalera (fotografía: Santiago Santos) leyenda elegida. Forma parte de todas esas tensiones institucionales que dejan su huella en las obras de arte.

Sin dudar de la interpretación expuesta, su elección ha de responder a una serie de acontecimientos en los que el Estudio se vio inmerso dentro del progresivo afianzamiento de la autoridad monárquica, en efecto en septiembre 1512 se constata la visita de don Diego Ramírez de Villaescusa. «Dicha visita no fue bien aceptada por el claustro universitario, manifestando una cierta resistencia corporativa frente al pretendido patronato regio [...] en cualquier caso, el claustro se enfrentó al Visitador, alegó constituir comunidad eclesiástica, con Constituciones y privilegios papales de cuya custodia era responsable el maestrescuela, y cuestionó la potestad regia para intervenir y visitar la universidad» (Rodríguez-San Pedro, 2013: 57). En ese contexto se dilucidan de lleno los cambios detectados en la clave y su reivindicación y aspiraciones proclamadas y perpetuadas a través de la imagen, pues «mostrarse en representación no significa estar ausente sino aparecer con ostentación» (Melot, 2010: 16) y así es como se exhibe el pontífice en la citada clave, semántica reforzada todavía más si cabe por la leyenda. Por otra parte, la clave con el motivo sigilar está policromada, donde destellan los tonos dorados y destaca el color rojo. El rojo se utilizaba en los matrices para subrayar la validez y especialmente la autoridad del sello (Serrano, 2006: 18). Todos estos cometidos se perfilan factibles en la clave de la escalera, buen ejemplo del funcionamiento social, las funciones ideológicas y el poder de las imágenes.

\section{En torno al sello de la fachada.}

de algunos monarcas como Fernando II, en ese caso se ha apelado a su cometido de reforzar la condición de autoridad. Se ha argumentado la función de representación de los sellos y cómo pueden personalizar al titular; con ese cometido debió actuar el sello de la escalera. En efecto, la imagen del Pontífice se privilegia, aparece incluso con nimbo, figurado por tanto como Santo Padre [4].

La lectura de reivindicación pontificia ha de entenderse, acaso, en el contexto de su rivalidad con la catedral y el cabildo, piénsese que se emplea cuando se ha empezado la construcción de la catedral nueva y en un juego de luchas de poder con el obispo y de competencias entre edificios. Que la universidad reivindique su condición pontificia superando el poder episcopal puede explicar el modelo y sobre todo la
El sello fijado en la fachada universitaria completa el corpus, resulta el más público, es el único que goza de una proyección urbana. En efecto, en ese tapiz petrificado (Lahoz, 2021) que es la portada se asiste también a la conmemoración de las figuras que han contribuido a su fundación y expansión, los Reyes Católicos en el tondo, con valor emblemático; el escudo del emperador, con carácter heráldico, y en la parte superior la figuración del sello universitario [5].

Por tanto se trata de motivo sigilar universitario, cuya presencia encarna y culmina el proyecto ideológico rector en la portada. En su figuración se prescinde del modelo habitual esclerotizado y se apuesta por un cuadro de escena viva, 
similar a las representaciones ad vivum. Y esa opción cercana, real, tangible, dinámica, interpretada en clave de vida cotidiana supera la condición alusiva y estereotipada de los poderes reales y dinásticos. Los diferentes modos de expresión, plenas de intención, rigen y denotan parte del significado del programa iconográfico. La caracterización escénica y narrativa de la trama superior, con el papa cobijado en una serliana y custodiado por los clérigos y cardenales, donde en su representación se recurre a una amplia gama de gradaciones volumétricas, cuya proyección denota el alcance de cada uno. La historiografía ha considerado de modo unánime que su tratamiento y tamaño responde a una función de perspectiva. El mayor volumen se imputaba a la necesidad de ser vista desde la estrecha calle, incluso como perspectiva inversa ha llegado a definirse. Sospecho que concurren razones de otro orden, de semántica y de significado. Frente a la condición emblemática y heráldica de las inferiores, la apuesta por una trama de naturaleza narrativa y desarrollo escénico está henchida de significado. A buen seguro responde a una retórica de contraste. $Y$ esa condición ad vivum señalada, reactiva de modo constante el poder de la institución universitaria autónomo y papal, como el claustro había esgrimido en 1512 ante la visita de Villaescusa y como se celebra en el sello de la Escalera. Se ha de pensar que responde a una retórica visual persuasiva. En su caracterización se podría definir como una escena diplomática, «no solo porque en ella se figura una carta de partida, sino porque también su imaginería habría de desempeñar la misma función que un documento, -sellar un pacto-» como se ha argumentado en la portada de Santa Ana de la catedral

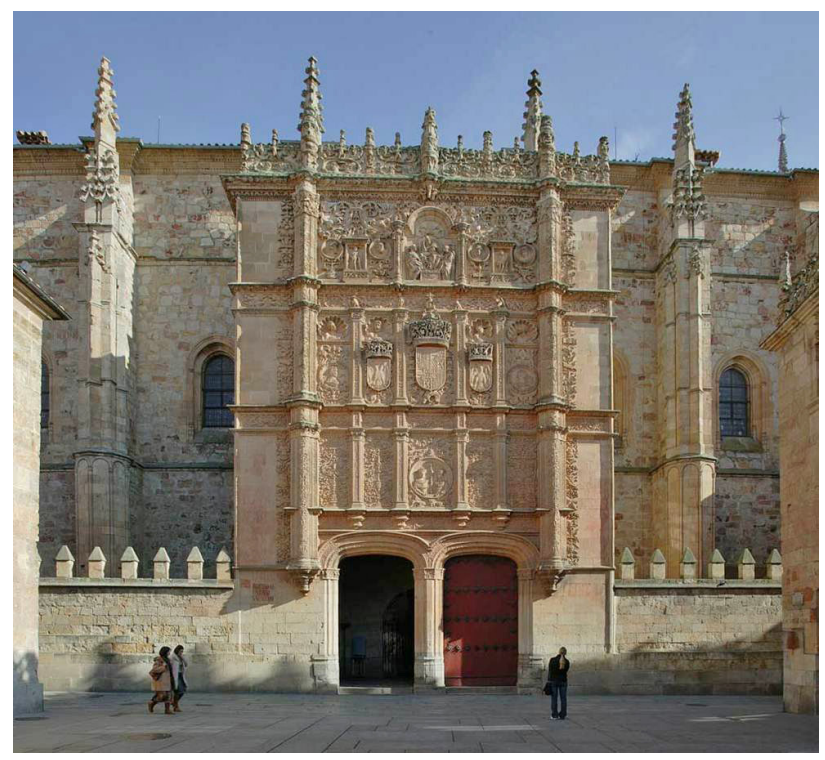

5. Portada Rica de la Universidad de Salamanca (fotografía: Santiago Santos)

de París (Sánchez, 2014: 72). La propia disposición en altura le dota de preeminencia, como sucede con la lectura de cualquier programa monumental al uso, donde la escena de más categoría ocupa el lugar superior. Me pregunto si toda la concepción del proyecto de la fachada Rica no parte de esa data donde el claustro se impone al visitador real, como sucedía en el sello de la escalera. No está de más plantear que todo obedece al mismo empeño, la escalera se realiza para ascender a la biblioteca y la fachada es la faz de esa biblioteca [6] y [7].

6. Detalle del sello ad vivum en la Portada Rica de la Universidad de Salamanca (fotografía: Santiago Santos)

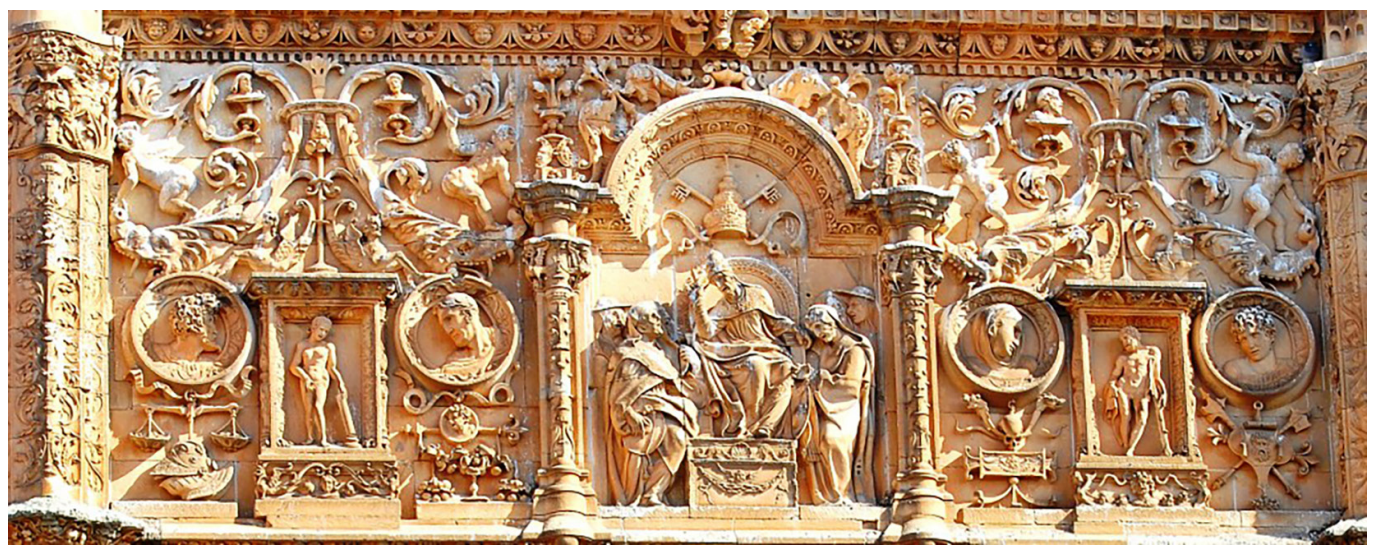




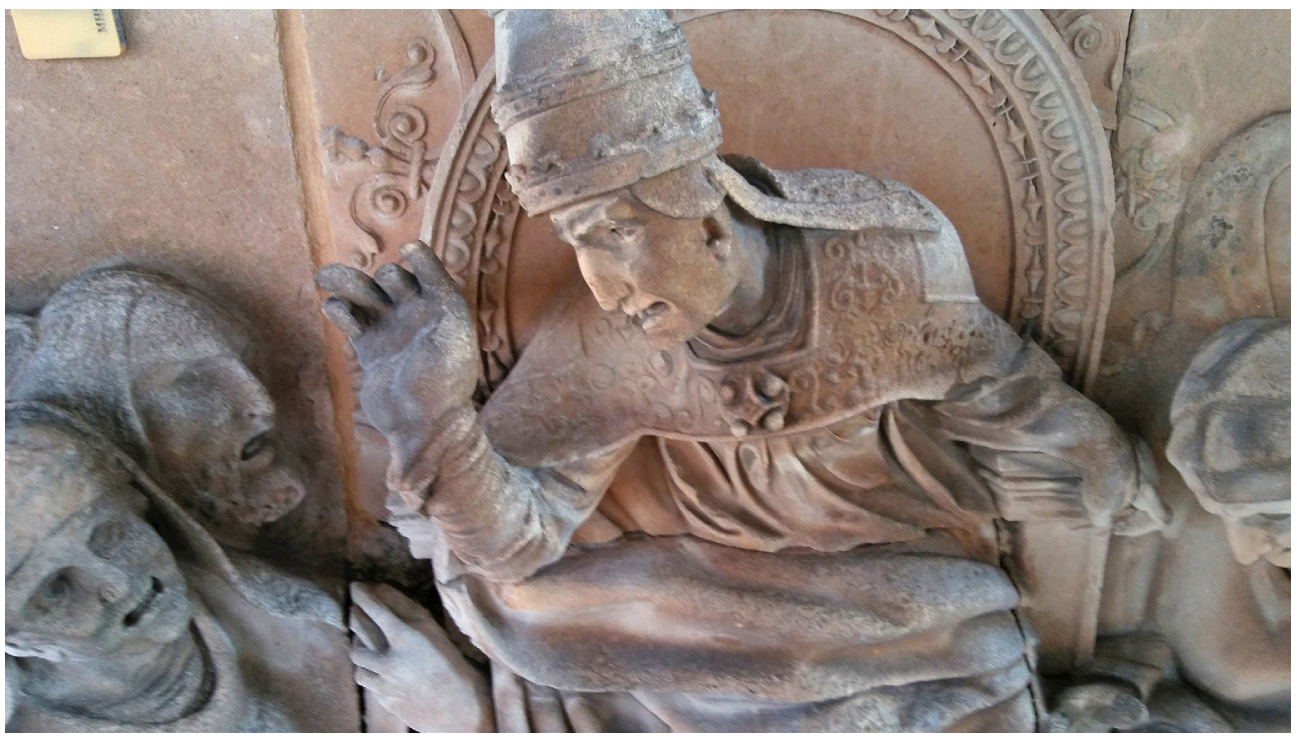

7. Detalle de la figura del pontífice en la Portada Rica (fotografía: Santiago Santos)

\section{Conclusiones}

En este rápido recorrido se ha dado cuenta de los motivos sigilares que decoran y condecoran el edificio del Estudio Salmantino. La academia ha utilizado otras variantes del sello, como aquella donde el profesor impartía la lectio, cuya leyenda celebraba las ciencias impartidas. No obstante, el registro sigilar que ha perdurado en la historia y en la vida de la institución universitaria salmantina es el modelo presidido por el Pontífice, piénsese incluso en su vigencia en el logo actual, pues dicha formula es la que hoy caracterizan la enseña universitaria. La solución da pie para la reflexión sobre la pervivencia de ese primer formato. ¿Porqué se vuelve a él, cuando sabemos que en determinadas épocas se ha modificado? De todos modos que dicho formato sea el que ha cristalizado resulta un referente de su proyección, buen reflejo de la memoria de su origen y de la perpetuación de su imagen, ejemplo de la pervivencia y de la memoria, conmemorando esa primera imagen papal. «Es necesario poner de nuevo el valor de la función de la imagen sigilar: la función de representar o de sustitución. La matriz o la impronta del sello puede sustituir a su poseedor en el ejercicio de sus ceremonias o sus obligaciones, en tal o cual ritual o ceremonia en tal o cual lugar donde el es imposible de estar» (Pastoreau, 1996: 298). Y como sos- tiene el mismo autor «la imagen del sello -aunque sea ella impronta, replica o forjada- es el sello y el sello es siempre la persona, muerta o viva, física o moral, real o imaginaria» (Pastoreau 1996: 298). El sello confirma y reivindica esa ascendencia pontificia que articula el estudio a lo largo de su historia y en el concurre esa primera «imagen» de validación papal.

De su significado y del alcance en el mundo medieval nos da idea el lugar donde se debe custodiar el sello, en numerosas ocasiones se pide de modo reiterado que se guarde en el arca de la universidad, acompañado de las constituciones y hasta de los dineros, en efecto la solución adoptada ayuda a matizar su consideración del sello como símbolo corporativo universitario, cuyo cometido semántico abarca todas sus facetas de validación jurisdiccional, de propiedad, de autoridad y de adscripción y hasta de representación apuntadas. Así en las Constituciones de Benedicto XIII, el papa Luna en el artículo 20 ordena:

Mandamos, además, que el sello, constituciones y privilegios del Estudio se guarden en el arca de la Universidad, también las doblas de graduados de bachiller, doctor o maestro, además de las cantidades de dinero debidas a sanciones y multas $\mathrm{u}$ otras aportaciones de la misma Universidad (Valero y Pérez, 1990: 131-149). 
Toda vez que los modelos monumentales abordados publicitan la idea de universidad papal, pero las opciones iconográficas y epigráficas delatan su propio momento histórico, auque entre ellos no medien ni diez años. Espléndido testimonio de la ideología, la política y el poder que articulan las imágenes si nos detenemos a entenderlas. Además en esos sellos pervive la memoria de la Universidad que se proclama por poco que nos detengamos a entenderlas.

\section{Notas}

1 El trabajo se inscribe dentro del proyecto de Investigación MINECO, Intermedialidad e institución. Relaciones interartísticas, literatura, audiovisual y artes plásticas. HAR201785392-P.

2 El motivo sigilar de la universidad inglesa, así como los referidos a continuación, se encuentran reproducidos en Hetmans, Jos M. M. y Nelisses, Marc (eds.) (1994), Chartrs of Foundation and Early Documents of the Universities ot the Coimbra Group, Croningem, p. 20.

\section{Bibliografía}

ALONSO ROMERO, Paz (2004), «Las constituciones medievales», en RODRÍGUEZ-SAN PEDRO BEZARES, Luis E. (ed.), Historia de la Universidad de Salamanca. Estructuras y flujos, t. II, Ediciones Universidad de Salamanca, Salamanca, p. 93-108.

ÁLVAREZ VILLAR, Julián (1994), Heráldica universitaria salmantina, Ediciones Universidad de Salamanca, Salamanca.

BELTRÁN DE HEREDIA, Vicente (1966), Bulario de la Universidad de Salamanca (1219-1549), Ediciones Universidad de Salamanca, Salamanca.

BEDOS-REZAK, Brigitte (2006), "L'au-delà du soi. Métamorphoses sigilaires en Europe médievale», Cahiers de civilitations medievale, n. ${ }^{\circ}$ 96, pp. 337-358.

CAMILLE, Michel (2005), Arte gótico. Visiones gloriosas, Akal, Madrid.

CARRASCO LAZARENO, María Teresa (2012), «El sello real en Castilla. Tipos y usos del sellado en la legislación y en la práctica documental (s. XII-XV)", en GALENDE DÍAZ, Juan Carlos; ÁVILA SEOANE, Nicolás y SANTIAGO MEDINA, Bárbara (eds.), De sellos y blasones: miscelánea científica, Universidad Complutense de Madrid, Madrid, pp. 63-170.

CASTRO SANTAMARÍA, Ana (1998), «Pedro de Larrea y Juan de Álava», Boletín del Museo Instituto Camón Aznar, LXXI, pp. 65-112.

DEBIAIS, Vicent (2013), «Mostrar, significar, desvelar. El acto de representar según las inscripciones», Codex aquilarensis: Cuadernos de investigación del Monasterio de Santa María la Real, n. ${ }^{\circ}$ 29, pp.169-186.

FABRE, Martine (2001), Sceau medieval, analyse d'une practique culturelle, L'Harmattan, París.

FERNANDEZ-XESTA y VAZQUEZ, Ernesto (2016), La sigilografía. Apuntes para la mejor práctica de investigadores, Confederación Española de Centros de Estudios Locales, Madrid.

GALENDE DÍAZ, Juan Carlos y ÁVILA SOANE, Nicolás (2018), El Rodado regio hispánico: León y Castilla antes de la unificación (12571230), Centro de Estudios Históricos Prof. Carlos S. A. Segreti, Córdoba (Argentina).

LAHOZ, Lucía (2014), «La imagen de la Universidad Pontificia», en PENA GONZÁLEZ, Miguel Anxo y RODRÍGUEZ-SAN PEDRO, Luis Enrique, La Universidad de Salamanca y el pontificado en la Edad Media, Ediciones Universidad de Salamanca, Salamanca, pp. $483-532$.

LAHOZ, Lucía (2021), «Imagen y memoria. La portada Rica de la Escuelas», en UNIVERSITAS. Las artes ante el tiempo. Actas del XXIII Congreso Nacional de Historia del Arte, Diputación de Salamanca-Universidad de Salamanca, Salamanca, en prensa.

LE POGAM, Pierre-Yves (1994-1996), «La matrice du grand sceau de l'Hôpital Saint-Jacques aux Pelerins par Jean Pucelle», Bulletin de la Societe Nationale des Anquaires de France, pp. 33-49.

MELOT, Michel (2010), Breve historia de la Imagen, Siruela, Madrid.

MENÉNDEZ PIDAL DE NAVASCUÉS, Faustino (1990), «La sigilografía española: una revisión crítica», Hispania: Revista española de historia, vol. 50, n. ${ }^{\circ} 175$, pp. $987-1002$. 
MENÉNDEZ PIDAL DE NAVASCUÉS, Faustino (2018), Los sellos en nuestra historia, Real Academia de la Historia/Boletín Oficial del Estado, Madrid.

MICHAUD-QUANTIN, Pierre (1970), Universitas. Expresions du mouvement communitaire dans Moyen Age latin, Vrin, París.

PASTOREAU, Michel (1986), «Les graveurs de sceaux et la création emblématique», en BARRAL i ALTET, Xavier (coord.), Artistes, artisans et production artistique au Moyen Age, volume I: Les hommes. Colloque international, Centre National de la Recherche Scientifique, Université de Rennes II-Haute-Bretagne, 2-6 mai 1983, Picard, París, pp. 515-522.

PASTOREAU, Michel (1988), «La naisance de la médaille, des impasses historiografiques à la theorie de l'image», Revue numismatique, $6^{\circ}$ serie, t. 30, pp. 227-248.

PASTOREAU, Michel (1996), «Les sceaux et la fonction sociale des images», en BASCHET, Jérôme y SCHIMITT, Jean Claude (dirs.), L'image. Fontions et usages des images dans l'Occident medievale, Les Cahiers du Léopard, París, pp. 275-309.

SÁNCHEZ AMEIJEIRAS, Rocío (2014), Los rostros de las palabras. Imágenes y teoría literaria en el Occidente Medieval, Akal, Madrid.

RODRíGUEZ DE SAN PEDRO, Luis E. (2013), «El canonista Diego de Covarrubias y Leyva (1512-1577) y la Universidad de Salamanca», Revista Española de Derecho Canónico, vol. 70, n. ${ }^{\circ}$ 174, pp. 41-65.

SCHAPIRO, Meyer (1996), «Frontal y perfil como forma simbólica», en Palabras, escritos e imágenes, ed. Encuentro, Madrid, pp. 59-82.

SCHMITT, Jean Claude (1999), «El historiador y las imágenes», Relaciones, n. ${ }^{\circ} 77$, pp. 17-47.

SERRANO COLL, Marta (2006), «Iconografía de género: los sellos de las reinas de Aragón en la Edad Media (siglos XII-XVI)», Emblemata, n. ${ }^{\circ} 12$, pp. 15-59.

VALERO GARCÍA, Pilar y PÉREZ MARTín, Manuel, (1990), «Pedro de Luna y el estudio Salmantino, Aspecto Institucional: su Constitución», Studia Historica. Historia Moderna, VIII, pp. 131-149. 